\title{
Study on chemotherapeutic sensitizing effect of nimotuzumab on different human esophageal squamous carcinoma cells
}

\author{
XIAOYU YANG ${ }^{1}$, YINGHUA $\mathrm{JI}^{2}$, XIAOCHUN $\mathrm{KANG}^{2}$, MEILING CHEN ${ }^{2}$, \\ WEIZHENG KOU ${ }^{2}$, CAILING JIN ${ }^{2}$ and PING LU ${ }^{2}$ \\ ${ }^{1}$ Department of Pathology, Xinxiang Medical University, Xinxiang, Henan 453003; ${ }^{2}$ Department of Oncology, \\ The First Affiliated Hospital of Xinxiang Medical University, Weihui, Henan 453100, P.R. China
}

Received September 21, 2015; Accepted December 2, 2015

DOI: $10.3892 / \mathrm{ol} .2015 .3989$

\begin{abstract}
Esophageal cancer is one of the leading causes of mortality worldwide. Although, surgery, radio- and chemotherapy are used to treat the disease, the identification of new drugs is crucial to increase the curative effect. The aim of the present study was to examine the chemotherapeutic sensitizing effect of nimotuzumab (h-R3) and cisplatin cytotoxic drugs cisplatin (DDP) and 5-fluorouracil (5-FU) on esophageal carcinoma cells with two different epidermal growth factor receptor (EGFR) expressions. The expression of EGFR was detected in the human EC1 or EC9706 esophageal squamous cell carcinoma cell line using immunohistochemistry. The inhibitory effect of DDP and 5-FU alone or combined with h-R3 on EC1 or EC9706 cell proliferation was detected using an MTT assay. Flow cytometry and the TUNEL assay were used to determine the effect of single or combined drug treatment on cell apoptosis. The results showed that the expression of EGFR was low in EC1 cells but high in EC9706 cells. The inhibitory effect of the single use of h-R3 on EC1 or EC9706 cell proliferation was decreased. The inhibitory effect between single use of h-R3 alone and combined use of the chemotherapy drugs showed no statistically significant difference $(\mathrm{P}>0.05)$ on the $\mathrm{EC1}$ cell growth rate, but showed a statistically significant difference $(a=0.05)$ on EC9706 cell growth rate. The results detected by flow cytometry and TUNEL assay showed that the difference between single use of h-R3 alone and the control group was statistically significant with regard to the EC1 apoptosis rate effect $(\mathrm{P}<0.05)$, but not statistically significant for EC9706 ( $P>0.05)$. However, statistically significant differences were identified in the apoptotic rate of EC9706 cells between the h-R3 combined chemotherapy group and single chemotherapy group $(\mathrm{P}<0.05)$, but not on in the EC1 chemotherapy group $(\mathrm{P}>0.05)$. In conclusion, the
\end{abstract}

Correspondence to: Dr Ping Lu, Department of Oncology, The First Affiliated Hospital of Xinxiang Medical University, 88 Jiangkang Road, Weihui, Henan 453100, P.R. China

E-mail: sunny8441_cn@sina.com

Key words: nimotuzumab, cisplatin, fluorouracil, esophageal carcinoma sensitization effect of h-R3 on chemotherapy drugs is associated with the expression level of EGFR in EC1 or EC9706 cells. The cell killing effect of the combined use of h-R3 with DDP and 5-FU showed no obvious synergistic effect compared to the single-drug group, but only an additive effect.

\section{Introduction}

Esophageal cancer is ranked the sixth leading cause of cancer mortalities worldwide (1). China has a high incidence of esophageal cancer, with $50 \%$ of new primary esophageal cancer patients being reported annually (2). In addition, 70\% of patients were diagnosed at advanced stage. The patients primarily underwent radio- and chemotherapy where surgery was not a feasible option. FD regimen treatment is the combined use of cisplatin (DDP) and 5-fluorouracil (5-FU) and constitutes the standard regimen for patients with advanced esophageal cell cancer (3). However, the partial remission rate is $<40 \%(4,5)$. Identification of new drugs to increase the curative effect of chemotherapy is therefore crucial.

Epidermal growth factor receptor (EGFR) is a member of the tyrosine kinase growth factor receptor family (6). Epidermal growth factor is overexpressed in many tumors. The overexpression of epidermal growth factor is associated with the genesis, metastasis, and poor prognosis of the tumor. EGFR inhibitor nimotuzumab (h-R3) has been shown to be effective in patients with non-small-cell lung cancer, colon cancer or head and neck cancer $(7,8)$. The results of related investigations on esophageal cancer demonstrate that h-R3 can increase the sensitivity of radiotherapy for esophageal carcinoma patients and increase the chemotherapy sensitivity of paclitaxel (9).

Another common scheme of FD for esophageal carcinoma was used in the present study to determine whether there are universal sensitization effects of h-R3 on chemotherapy drugs. Investigation on two cell types with different expression levels of EGFR was also performed to examine the correlation between the h-R3 effect and the expression level of EGFR.

\section{Materials and methods}

Cell culture. Human EC1 and EC9706 esophageal squamous cell carcinoma cells were provided by the Cancer Retroviral 
Molecular Biology Laboratory, Xinxiang Medical University (Xinxiang, China). The experimental h-R3 drug was a gift from Baitai Biological Pharmaceutical Co., Ltd. (Beijing, China). The cells were cultured in RPMI-1640 medium containing $10 \%$ (v/v) FBS, $100 \mathrm{U} / \mathrm{ml}$ penicillin and $100 \mathrm{~g} / \mathrm{ml}$ of streptomycin in an incubator at $37^{\circ} \mathrm{C}$ with $5 \% \mathrm{CO}_{2}$. The medium was changed every $24 \mathrm{~h}$ and the cells were passaged every $48 \mathrm{~h}$. The primary reagents were: DDP (Yunnan Biological Valley Breviscapin Pharmaceutical Co., Ltd., Yunnan, China), h-R3 (Baitai Biological Pharmaceutical Co., Ltd.), MTT assay (Beijing Xinjingke Biotechnology Co., Ltd., Beijing, China), apoptosis kit (Haimen City Pik Natural Technology Research Institute, Haimen, China) and TUNEL assay (Roche Diagnostics GmbH, Mannheim, Germany).

Detection of the expression of EGFR by immunohistochemical analysis. EC1 and EC9706 cells in the logarithmic growth phase were digested with trypsin after the cells were counted. The cells were suspended on a slide and then seeded at a concentration of $0.01 \mathrm{~mol} / \mathrm{l}$. PBS $(0.01 \mathrm{~mol} / \mathrm{l})$ was applied in and around the slide to prevent liquid evaporation. Approximately $3 \% \mathrm{H}_{2} \mathrm{O}_{2}$ was used to eliminate the peroxidase after $24 \mathrm{~h}$. Antigen retrieval was achieved using a microwave oven. Goat serum was used for blocking. The primary antibody (rabbit, 1:50, ab2430, Abcam, Cambridge, UK) dilution was incubated overnight at $4^{\circ} \mathrm{C}$. The secondary antibody (goat, 1:500, ab97051, Abcam) was added and stained with DAB. Cell membrane expressions of EGFR in the two groups were observed under a microscope (IE 2000U Nikon Corporation, Tokyo, Japan). Nuclear staining was considered as positive for EGFR. The intensity of the staining was scored as: $(+),(++)$, $(+++)$ scores with $1-25 \%, 25-50 \%$ and $>50 \%$ cells showing positive staining, respectively.

Detection of the inhibitory effect of MTT assay on esophageal carcinoma cells. The cells were divided into the control, h-R3, DDP, 5-FU groups, as well as h-R3 combined with DDP group, and h-R3 combined with 5-FU group. EC1 cells in the logarithmic growth phase were digested and centrifuged for cell counting. The cells were seeded in a 96-well plate at a density of $5 \times 10^{3}$ cells and $100 \mu \mathrm{l}$ of medium (DMEM) was placed in each well and cultured at $37^{\circ} \mathrm{C}$ with $5 \% \mathrm{CO}_{2}$ for $24 \mathrm{~h}$. Different doses of the drug were added in each group. The concentration of a single use of h-R3 was $12.5,25,50,100$, 200 and $400 \mu \mathrm{g} / \mathrm{ml}$, respectively; while that of DDP was 0.25 , $0.5,1,1.5,2$ and $2.5 \mu \mathrm{g} / \mathrm{ml}$, respectively; and 5 -FU was $0.5,1$, 2, 4, 6 and $8 \mu \mathrm{g} / \mathrm{ml}$, respectively. The blank group was added without any drug.

The cells were cultured for $48 \mathrm{~h}$. Subsequently, $20 \mu \mathrm{l}$ MTT $(5 \mathrm{mg} / \mathrm{ml})$ assay was applied and the cells were inoculated at $37^{\circ} \mathrm{C}$ for $4 \mathrm{~h}$. The medium was removed, washed with PBS, and DMSO was added prior to 10-min agitation. The optical density (OD) value for each well was detected using an enzyme-linked immune monitor at the wavelength of $492 \mathrm{~nm}$, and the results were recorded. The experiments were conducted with six parallel wells, repeated three times, and an average was applied.

The cell growth inhibition rate (\%) was calculated as: 1 (the OD value of experimental group/control group) x $100 \%$. The 30\% inhibitive concentration (IC30) of the drug combination of the DDP and 5-FU was calculated according to the concentration curve. It was used for the drug concentration of the combined drug therapy. The h-R3 concentration in the combined drug therapy was $100 \mu \mathrm{g} / \mathrm{ml}$. Given that the drug concentration was the abscissa axis and the cell inhibition rate the vertical axis, the drug concentration cell inhibition rate curve with the experimental results was drawn.

The cytotoxicity induced by the two drugs combined with application of Jin's formula was calculated. The interaction index was shown as $\mathrm{q}$, and the formula used was: $q=E(A B) /[E A+(1-E A) \times E B]$, where $E(A B)$ was the growth inhibition rate of the combined use of the two drugs. EA and EB were the growth inhibition rate of the single use of the drug. If the q-value was in the range of $0.85-1.15$, it indicated that the effects of the two drug were additive. A q-value of $>1.15$ indicated that the two drugs exerted a cooperative effect. A q-value of $<0.85$ representing the combination of the two drugs exerted an antagonistic effect.

Detection of cell apoptosis using flow cytometry. The cells in the logarithmic growth phase were seeded in a 6 -well plate at a density of $1 \times 10^{5} / \mathrm{ml}$ and were treated with $100 \mu \mathrm{g} / \mathrm{ml} \mathrm{h}-\mathrm{R} 3$, $0.5 \mu \mathrm{g} / \mathrm{ml}$ DDP, $1 \mu \mathrm{g} / \mathrm{ml} 5-\mathrm{FU}, 100 \mu \mathrm{g} / \mathrm{ml}$ h-R3 combined with $0.5 \mu \mathrm{g} / \mathrm{ml}$ DDP, and $100 \mu \mathrm{g} / \mathrm{ml} \mathrm{h}-\mathrm{R} 3$ combined with $1 \mu \mathrm{g} / \mathrm{ml}$ 5 -FU, respectively, after $24 \mathrm{~h}$. A corresponding volume of culture medium was added to the control group, and the cells were incubated at $37^{\circ} \mathrm{C}$ with $5 \% \mathrm{CO}_{2}$ for $48 \mathrm{~h}$. The cells were collected and the supernatant was discarded. Subsequently, the cells were washed with PBS, centrifuged at $800 \mathrm{x}$ g for $5 \mathrm{~min}$. The supernatant was discarded and Annexin V-fluorescein isothiocyanate (FITC) was added for cell suspension and incubated in the dark for $10 \mathrm{~min}$ at room temperature $\left(25^{\circ} \mathrm{C}\right)$, followed by centrifugation at $800 \mathrm{x}$ g for $5 \mathrm{~min}$. The solution (fix liquid) was removed, Annexin V-FITC was added for cell suspenstion, followed by the addition of propidium iodide staining solution and mixing thereof. The cells were placed in an ice bath for $5 \mathrm{~min}$ for staining in the dark and the cell cycle was detected using flow cytometry.

Detection of cell apoptosis using the TUNEL assay. Single cell suspension was prepared and cells were seeded in the dish containing the slide at a density of $1 \times 10^{5}$ cells $/ \mathrm{ml}$. Cell treatment was the same as for the flow cytometry following adherence to the wall of the dish. After $48 \mathrm{~h}$ of culture, the slide was washed with PBS three times, and fixed in $4 \%$ paraformaldehyde for $40 \mathrm{~min}$, washed with PBS for $3 \times 3 \mathrm{~min}$, blocked at room temperature $\left(25^{\circ} \mathrm{C}\right)$ for $10 \mathrm{~min}$, and washed again with PBS for $3 \times 3 \mathrm{~min}$. The slide was then placed at $4^{\circ} \mathrm{C}$ for $3 \mathrm{~min}$ and washed with PBS for $3 \times 5 \mathrm{~min}$, prior to $50 \mu \mathrm{l}$ conversion solution being added and reaction at $37^{\circ} \mathrm{C}$ in wet and dark conditions for $30 \mathrm{~min}$. The slide was again washed with PBS for $3 \times 5 \mathrm{~min}$, stained with DAB and observed under the microscope (IE 2000U Nikon Corporation). After counterstaining with hematoxylin, the cells were dehydrated in alcohol, cleared in $\mathrm{H}_{2} \mathrm{O}$ and mounted with paraformaldehyde, and observed under the microscope (IE 2000U Nikon Corporation). The proportion of apoptotic cells was calculated. The nuclei of the apoptotic cells under the microscope (magnification at x400, IE 2000U Nikon Corporation) had a precipitation of brown yellow granules, which was accumulated at the nuclear periphery, while the nuclei of the non-apoptotic cells were blue. 


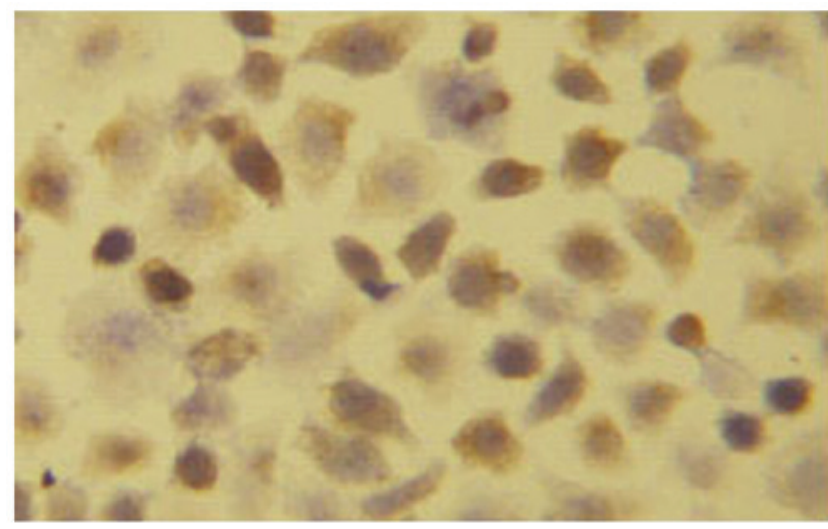

Figure 1. Low expression of EC1 cells in EGFR. Magnification, x400.

Table I. Cell growth inhibition rate of esophageal squamous carcinoma with different concentrations of h-R3 treatment alone $(\%$, mean \pm standard deviation, $n=6)$.

\begin{tabular}{lcc}
\hline & \multicolumn{2}{c}{ Reaction period, $48 \mathrm{~h}$} \\
\cline { 2 - 3 } Drug concentration, $\mu \mathrm{g} / \mathrm{ml}$ & $\mathrm{EC} 1$ & $\mathrm{EC9706}$ \\
\hline 12.5 & $1.15 \pm 0.04$ & $3.01 \pm 0.11$ \\
25 & $5.12 \pm 0.48$ & $10.24 \pm 1.23$ \\
50 & $8.83 \pm 0.75$ & $17.20 \pm 0.98$ \\
100 & $9.09 \pm 0.48$ & $26.57 \pm 3.34$ \\
200 & $9.34 \pm 0.72$ & $27.84 \pm 2.42$ \\
400 & $10.10 \pm 0.58$ & $27.35 \pm 1.95$ \\
\hline h-R3, nimotuzumab. & & \\
\hline \multicolumn{3}{l}{} \\
\multicolumn{3}{l}{ Table II. Cell growth inhibition rate of esophageal squamous } \\
carcinoma at different concentrations of DDP treatment alone \\
(\%, mean \pm standard deviation, n=6).
\end{tabular}

\begin{tabular}{lcc}
\hline & \multicolumn{2}{c}{$\begin{array}{c}\text { The 48-h drug } \\
\text { inhibition rate, } \%\end{array}$} \\
\cline { 2 - 3 } The drug concentration, $\mu \mathrm{g} / \mathrm{ml}$ & $\mathrm{EC1}$ & EC9706 \\
\hline 0.25 & $18.44 \pm 1.77$ & $20.26 \pm 2.79$ \\
0.5 & $36.04 \pm 2.68$ & $36.49 \pm 4.60$ \\
1 & $49.52 \pm 3.49$ & $52.62 \pm 5.24$ \\
1.5 & $71.31 \pm 4.43$ & $74.83 \pm 5.34$ \\
2.5 & $83.29 \pm 6.38$ & $84.79 \pm 2.09$ \\
& $90.37 \pm 7.72$ & $92.21 \pm 6.86$ \\
\hline
\end{tabular}

DDP, cisplatin.

Statistical analysis. Statistical analysis was performed using the Shapiro-Wilk advanced tests of normality, as well as homogeneity of variance test, paired t-test, analysis of variance (normal distribution and homogeneity of variance) or rank sum test. The experimental data were presented as

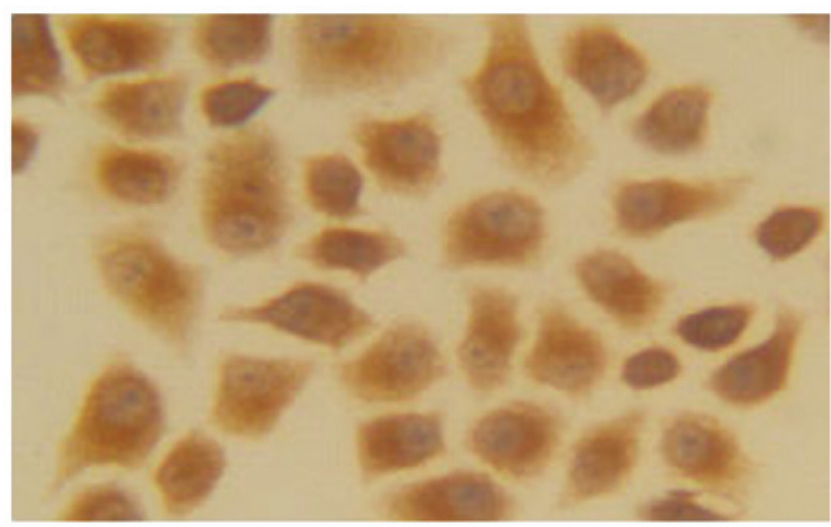

Figure 2. High EC9706 cell expression in EGFR. Magnification, x400.

Table III. Cell growth inhibition rate of esophageal squamous carcinoma at different concentrations of 5-FU treatment alone $(\%$, mean \pm standard deviation, $\mathrm{n}=6)$.

\begin{tabular}{lcc}
\hline & \multicolumn{2}{c}{$\begin{array}{c}\text { The 48-h drug } \\
\text { inhibition rate, } \%\end{array}$} \\
\cline { 2 - 3 } Drug concentration, $\mu \mathrm{g} / \mathrm{ml}$ & $\mathrm{EC} 1$ & EC9706 \\
\hline 0.5 & $12.00 \pm 1.59$ & $14.01 \pm 1.10$ \\
1 & $27.66 \pm 3.02$ & $30.17 \pm 0.94$ \\
2 & $45.80 \pm 3.38$ & $48.23 \pm 4.56$ \\
4 & $64.95 \pm 2.18$ & $67.14 \pm 5.13$ \\
6 & $74.10 \pm 7.27$ & $79.05 \pm 3.56$ \\
8 & $89.27 \pm 6.47$ & $90.51 \pm 6.11$ \\
\hline
\end{tabular}

5-FU, 5-fluorouracil.

mean \pm standard deviation. The statistical software used to analyze the data was SPSS 17 (SPSS, Inc., Chicago, IL, USA). The significance level was $\alpha=0.05$.

\section{Results}

Immunohistochemistry. The EC1-positive cells were $22.45 \pm 2.54 \%(+)$, suggesting that a low expression of EC1 cells in EGFR. The number of EC9706-positive cells was $91.22 \pm 4.65 \%(+++)$, indicating that EC9706 cells were highly expressed in EGFR (Figs.. 1 and 2).

Detection of the human esophageal cancer cell growth inhibition of the combined drug treatment using the MTT assay. Detection of the effect of different concentrations of h-R3 on EC1 and EC9706 cells via the MTT assay showed no obvious inhibitory action on the tumor cells after $48 \mathrm{~h}$. The highest growth inhibitory rate on EC1 cells in vitro was only $10 \%$ when the single use of h-R3 concentration was $\leq 400 \mu \mathrm{g} / \mathrm{ml}$. By contrast, the highest growth inhibitory rate on EC9706 cells in vitro was $30 \%$. A comparison of EC1 with EC9706 showed that the difference in the growth inhibition rate between the two cell lines after h-R3 treatment was significant, while the latter effect was stronger than the former $(\mathrm{P}<0.01)$ (Table I). 
Table IV. Cell growth inhibition rate of esophageal squamous carcinoma with single or combined use of DDP and/or 5-FU (\%, mean \pm standard deviation, $n=6)$.

The 48-h drug inhibition rate, $\%$

\begin{tabular}{|c|c|c|c|c|}
\hline & & & & \\
\hline \multirow[b]{2}{*}{ Processing method } & \multirow{2}{*}{$\frac{\mathrm{h}-\mathrm{R} 3}{\mathrm{a}}$} & \multicolumn{2}{|c|}{ DDP/5-FU combined use } & \multirow{2}{*}{$\frac{\text { P-and q-value }}{\text { b vs. c }}$} \\
\hline & & $\mathrm{b}$ & $\mathrm{c}$ & \\
\hline \multicolumn{5}{|l|}{ h-R3/DDP } \\
\hline $\mathrm{EC} 1$ & $8.50 \pm 1.13$ & $36.07 \pm 3.25$ & $35.88 \pm 3.89$ & 0.930 vs. 0.86 \\
\hline EC9706 & $25.85 \pm 2.04$ & $35.93 \pm 2.01$ & $47.83 \pm 3.07$ & 0.000 vs. 0.91 \\
\hline \multicolumn{5}{|l|}{ 5-FU/h-R3 } \\
\hline $\mathrm{EC} 1$ & $8.50 \pm 1.23$ & $31.19 \pm 3.60$ & $30.99 \pm 2.28$ & 0.909 vs. 0.85 \\
\hline EC9706 & $25.85 \pm 2.04$ & $30.97 \pm 1.06$ & $46.23 \pm 3.16$ & 0.000 vs. 0.95 \\
\hline
\end{tabular}

Nimotuzumab (h-R3): $100 \mu \mathrm{g} / \mathrm{ml}$; cisplatin (DDP): $0.5 \mu \mathrm{g} / \mathrm{ml}$; 5-fluorouracil (5-FU): $1 \mu \mathrm{g} / \mathrm{ml}$.

Table V. Detection results of apoptotic cells of the different treatment groups $(\%$, mean \pm standard deviation, $n=3)$.

\begin{tabular}{|c|c|c|c|}
\hline \multirow[b]{2}{*}{$\begin{array}{l}\text { Treatment factors } \\
\text { (Group) }\end{array}$} & \multicolumn{3}{|c|}{ Apoptosis rate, \% } \\
\hline & EC1 & EC9706 $p^{a}$ & P-value \\
\hline Control & $3.54 \pm 0.37$ & $3.86 \pm 0.22$ & \\
\hline h-R3 & $4.31 \pm 0.69$ & $5.45 \pm 0.63^{\mathrm{b}}$ & \\
\hline DDP & $9.88 \pm 0.25^{\mathrm{b}}$ & $0.92 \pm 2.20^{\mathrm{b}}$ & \\
\hline DDP+h-R3 & $10.25 \pm 1.18^{\mathrm{b}}$ & $17.49 \pm 1.04^{\mathrm{b}}$ & $0.489^{c}$ \\
\hline $5-\mathrm{FU}$ & $8.09 \pm 0.17^{b}$ & $12.48 \pm 2.66^{\mathrm{b}}$ & \\
\hline 5-FU+h-R3 & $8.15 \pm 0.32^{b}$ & $17.51 \pm 0.66^{\mathrm{b}}$ & $0.833^{\mathrm{c}}$ \\
\hline \multicolumn{4}{|c|}{$\begin{array}{l}\text { Nimotuzumab (h-R3): } 100 \mu \mathrm{g} / \mathrm{ml} \text {; cisplatin (DDP): } 0.5 \mu \mathrm{g} / \mathrm{ml} \text {; } 5 \text {-fluo- } \\
\text { rouracil }(5-\mathrm{FU}): 1 \mu \mathrm{g} / \mathrm{ml} .{ }^{\mathrm{a}} \mathrm{p} \text { is the comparison of the apoptotic rate } \\
\text { of EC } 9706 \text { between the combined drug use and chemotherapy drug } \\
\text { alone groups. }{ }^{\mathrm{b}} \text { Means comparison with the control group, } \mathrm{P}<0.05 \text {. } \\
\text { 'Indicates the comparison of the apoptotic rate between the combined } \\
\text { drug use and chemotherapy drug alone groups, } \mathrm{P}<0.05 \text {. }\end{array}$} \\
\hline
\end{tabular}

DDP and 5-FU treatment of EC1 and EC9706 cells after different concentrations identified a dose-dependent increase in the inhibition rate. Cell growth inhibition rates following treatment with different concentrations of DDP showed a statistically significant difference $(\mathrm{P}<0.05)$. Cell growth inhibition rates following treatment with different concentrations of 5-FU showed a statistically significant difference at the same time $(\mathrm{P}<0.05)$ (Tables II and III). According to the gradient changing curve of the relationship between the inhibitory rate of cell growth and drug concentration, $30 \%$ IC30 of DDP on esophageal EC1 and EC9706 carcinoma cells after $48 \mathrm{~h}$ treatment was $0.5 \mu \mathrm{g} / \mathrm{ml}$. Table II shows the corresponding drug concentration when the cell inhibitory rate was $30 \%$, was $0.5 \mu \mathrm{g} / \mathrm{ml}$, which is in accordance with results calculated using the equation. The IC30 of 5-FU treatment of esophageal EC1 and EC9706 carcinoma cells after $48 \mathrm{~h}$ was $1 \mu \mathrm{g} / \mathrm{ml}$.
Table VI. Detection results of apoptotic cell of different treatment groups (\%, mean \pm standard deviation, $\mathrm{n}=3$ ).

\begin{tabular}{lccc}
\hline & \multicolumn{3}{c}{ Apoptosis rate, \% } \\
\cline { 2 - 4 } $\begin{array}{l}\text { Treatment factors } \\
\text { (Group) }\end{array}$ & EC1 & EC9706 $\mathrm{p}^{\mathrm{a}}$ & P-value \\
\hline Control & & & \\
h-R3 & $1.96 \pm 0.14$ & $2.11 \pm 0.32$ & \\
DDP & $2.02 \pm 0.14$ & $3.92 \pm 0.87^{\mathrm{b}}$ & \\
DDP+h-R3 & $6.91 \pm 0.83^{\mathrm{b}}$ & $8.00 \pm 0.46^{\mathrm{b}}$ & \\
5-FU & $7.01 \pm 0.55^{\mathrm{b}}$ & $12.18 \pm 0.50^{\mathrm{b}}$ & $0.672^{\mathrm{c}}$ \\
5-FU+h-R3 & $5.98 \pm 0.24^{\mathrm{b}}$ & $7.32 \pm 0.71^{\mathrm{b}}$ & \\
\hline
\end{tabular}

Nimotuzumab (h-R3): $100 \mu \mathrm{g} / \mathrm{ml}$; cisplatin (DDP): $0.5 \mu \mathrm{g} / \mathrm{ml}$; 5-fluorouracil (5-FU): $1 \mu \mathrm{g} / \mathrm{ml}$. ${ }^{\mathrm{a}} \mathrm{p}$ is the comparison of the apoptotic rate of EC9706 between the combined drug use and chemotherapy drug alone groups. ${ }^{b}$ Means comparison with the control group, $\mathrm{P}<0.05$. 'Indicates comparison of the apoptotic rate between the combined drug use and chemotherapy drug alone groups, $\mathrm{P}<0.05$.

Cell growth inhibitory effect of the combined treatment on human esophageal cancer. The h-R3, DDP and 5-FU drugs were used at concentrations of $100 \mu \mathrm{g} / \mathrm{ml}, 0.5 \mu \mathrm{g} / \mathrm{ml}$ and $1 \mu \mathrm{g} / \mathrm{ml}$, respectively, with a reaction time of $48 \mathrm{~h}$. The difference of the cell growth inhibition rate between the use of h-R3 combined with the chemotherapy drug and chemotherapy drug alone groups in the EC1 cells was not statistically significant following the treatment with the given concentrations $(\mathrm{P}>0.05)$. By contrast, the differences of the cell growth inhibition rate between the combined use of the chemotherapy drug and chemotherapy drug alone groups were statistically significant $(\mathrm{P}<0.01)$ (Table IV).

Cytotoxicity induced by combined application of the two drugs was calculated using Jin's formula. The interaction index was represented with as a q-value and the formula used was $\mathrm{q}=\mathrm{E}(\mathrm{AB}) /[\mathrm{EA}+(1-\mathrm{EA}) \times \mathrm{EB}]$. The q-value of the combined effect of the two drugs was $<1.15$, which is in the range 
of $0.85-1.15$, indicating that it has a combined effect of the two drugs (Table IV).

Apoptotic cell analysis using flow cytometry. The apoptotic rate difference of the EC1 esophageal cancer cells between the control group and h-R3 group was statistically significant $(\mathrm{P}>0.05)$. The rate of apoptosis between single use of DDP, $5-\mathrm{FU}$ or the combination with h-R3 group with the control group was statistically significant $(\mathrm{P}<0.05)$. The combined chemotherapy and drug alone groups did not yield any significant difference with regard to the apoptotic rate $(\mathrm{P}>0.05)$. However, the EC9706 esophageal carcinoma cell apoptotic rate between the drug treatment and control groups was statistically different $(\mathrm{P}<0.05)$. The difference between the combined drug use and chemotherapy alone groups with regard to the drug apoptotic rate was statistically significant $(\mathrm{P}<0.05)($ Table V).

Apoptotic cell analysis using TUNEL. The TUNEL assay was used to detect cell apoptosis. The nuclei of the apoptotic cells under the microscope (magnification at $\mathrm{x} 400$, (IE 2000U Nikon Corporation) had a precipitation of brown yellow granules, which was accumulated at the nuclear periphery, while the nuclei of the non-apoptotic cells were blue.

The results were similar to the measured results of the flow cytometry. The apoptotic rate difference of the EC1 esophageal cancer cells between the control and h-R3 groups was not statistically significant $(\mathrm{P}>0.05)$. The apoptotic rate of DDP and 5-FU single use therapy or combination with the h-R3 compared to the control group showed a statistically significant difference $(\mathrm{P}<0.05)$. The apoptotic rate between the combined use drug and chemotherapy drug alone groups was not significantly different $(\mathrm{P}>0.05)$. The difference in the apoptotic rate of EC9706 esophageal cancer cells between the control and h-R3 groups was statistically significant $(\mathrm{P}<0.05)$. The apoptotic rate of the single and combinatorial use therapy groups was statistically significant $(\mathrm{P}<0.05)$. The difference of the combined apoptotic rate of the combination and single drug groups was not statistically significant $(\mathrm{P}>0.05)$ (Table VI).

\section{Discussion}

Molecular-targeted therapy has recently become a hotspot, particularly investigations regarding EGFR. h-R3 is the first humanized monoclonal antibody used for the treatment of malignant tumors. It was recommended by the National Comprehensive Cancer Network (Chinese version) Head and Neck Tumor of Treatment Guidelines in 2009. Clinical and basic studies in recent years have confirmed its effect and safety in the treatment of head and neck cancer, glioma, gastric cancer, nasopharyngeal carcinoma and other solid tumors $(7,8)$. Findings of previous studies on esophageal cancer have identified that h-R3 is capable of increasing the sensitivity of radiotherapy in esophageal carcinoma as well as paclitaxel chemotherapy sensitivity (9).

Through comparison of two types of human squamous cell carcinoma of esophagus, our in vitro experiment results show that the sensitization effect in EC9706 cells with a high expression of EGFR is better than that in EC1 cells with a low expression of EGFR. Thus, the antitumor effect of the EGFR-specific monoclonal antibody occurs by blocking the binding of ligand and EGFR, thereby influencing EGFR activity and downstream signaling pathway transmission, inhibiting tumor cell proliferation, arresting cell cycle progress, inducing tumor cell apoptosis and inhibiting tumor angiogenesis. The h-R3 is a humanized EGFR monoclonal antibody, which can be combined stably in the bivalent form with EGFR receptors on the cell surface (10). The h-R3 shows moderate affinity for EGFR, but has a high affinity for tumor cells with highly expressed EGFR. Thus, it is capable of stabilizing its surface receptor, while for tumor cells with a low expression EGFR or normal tissue cells it shows low affinity. This may be the reason for the sensitizing effect of h-R3 on chemotherapy drugs resulting in a high expression of EGFR in EC9706 cells as compared to EC1 cells with a lower expression of EGFR.

However, the cytocidal effect of h-R3 combined with DDP and 5-FU showed no obvious synergistic effect compared to the single drug alone treatment, although an additive effect was evident. Investigation of the EGFR monoclonal antibody demonstrated that C225 ligand can induce EGFR to migrate into the nucleus (11). Previous findings $(12,13)$ have confirmed that $\mathrm{C} 225$ is directly associated with chemotherapy resistance, which means nuclear EGFR is possibly associated with EGFR-targeted therapy effect. Therefore, EGFR nuclear translocation was also associated with the drug resistance of h-R3. There are also studies (14-16) suggesting that it may be associated with the decrease of AKT activity mediated by anti-EGFR antibody and EGFR internalization and degradation disorder. Thus, the possible mechanisms of current anti-EGFR monoclonal antibody combined with chemotherapy drug synergy effect remain to be determined.

In summary, the results of the present study show that h-R3 can increase the sensitivity of FD scheme chemotherapy for esophageal carcinoma, and shows no synergistic effect but only an additive effect. The effect of h-R3 on chemotherapy sensitization is positively associated with a high expression of EGFR.

\section{References}

1. Long E and Beales IL: The role of obesity in oesophageal cancer development. Therap Adv Gastroenterol 7: 247-268, 2014.

2. Fischer OM, Hart S, Gschwind A and Ullrich A: EGFR signal transactivation in cancer cells. Biochem Soc Trans 31: 1203-1208, 2003.

3. Yu CL, Meyer DJ, Campbell GS, Larner AC, Carter-Su C, Schwartz J and Jove R: Enhanced DNA-binding activity of a Stat3-related protein in cells transformed by the Src oncoprotein. Science 269: 81-83, 1995.

4. Adams GP and Weiner LM: Monoclonal antibody therapy of cancer. Nat Biotechnol 23: 1147-1157, 2005.

5. Wang YN, Yamaguchi H, Hsu JM and Hung MC: Nuclear trafficking of the epidermal growth factor receptor family membrane proteins. Oncogene 29: 3997-4006, 2010.

6. Diaz Miqueli A, Blanco R, Garcia B, Badia T, Batista AE, Alonso $\mathrm{R}$ and Montero E: Biological activity in vitro of anti-epidermal growth factor receptor monoclonal antibodies with different affinities. Hybridoma (Larchmt) 26: 423-431, 2007.

7. Rojo F, Gracias E, Villena N, Cruz T, Corominas JM, Corradino I, Cedeño M, Campas C, Osorio M, Iznaga N, et al: Pharmacodynamic trial of nimotuzumab in unresectable squamous cell carcinoma of the head and neck: a SENDO Foundation study. Clin Cancer Res 16: 2474-2482, 2010.

8. Bebb G, Smith C, Rorke S, Boland W, Nicacio L, Sukhoo R and Brade A: Phase I clinical trial of the anti-EGFR monoclonal antibody nimotuzumab with concurrent external thoracic radiotherapy in Canadian patients diagnosed with stage IIb, III or IV non-small cell lung cancer unsuitable for radical therapy. Cancer Chemother Pharmacol 67: 837-845, 2011. 
9. Pandey A, Noronha V, Joshi A, Tongaonkar H, Bakshi G and Prabhash K: Resistant metastatic penile carcinoma and response to biochemotherapy with paclitaxel and epidermal growth factor receptor monoclonal antibody, nimotuzumab. Indian J Med Paediatr Oncol 34: 24-27, 2013.

10. Garrido G, Tikhomirov IA, Rabasa A, Yang E, Gracia E, Iznaga N, Fernández LE, Crombet T, Kerbel RS and Pérez R: Bivalent binding by intermediate affinity of nimotuzumab: a contribution to explain antibody clinical profile. Cancer Biol Ther 11: 373-382, 2011 .

11. Lu Y, Li X, Liang K, Luwor R, Siddik ZH, Mills GB, Mendelsohn J and Fan Z: Epidermal growth factor receptor (EGFR) ubiquitination as a mechanism of acquired resistance escaping treatment by the anti-EGFR monoclonal antibody cetuximab. Cancer Res 67: 8240-8247, 2007.

12. Liccardi G, Hartley JA and Hochhauser D: EGFR nuclear translocation modulates DNA repair following cisplatin and ionizing radiation treatment. Cancer Res 71: 1103-1114, 2011.

13. Dittmann K, Mayer C, Fehrenbacher B, Schaller M, Kehlbach R and Rodemann HP: Nuclear EGFR shuttling induced by ionizing radiation is regulated by phosphorylation at residue Thr654. FEBS Lett 584: 3878-3884, 2010.
14. Wheeler DL, Huang S, Kruser TJ, Nechrebecki MM, Armstrong EA, Benavente S, Gondi V, Hsu KT and Harari PM: Mechanisms of acquired resistance to cetuximab: role of HER (ErbB) family members. Oncogene 27: 3944-3956, 2008.

15. Loupakis F, Pollina L, Stasi I, Ruzzo A, Scartozzi M, Santini D, Masi G, Graziano F, Cremolini C, Rulli E, et al: PTEN expression and KRAS mutations on primary tumors and metastases in the prediction of benefit from cetuximab plus irinotecan for patients with metastatic colorectal cancer. J Clin Oncol 27: 2622-2629, 2009.

16. Kim SM, Kim JS, Kim JH, Yun CO, Kim EM, Kim HK, Solca F, Choi SY and Cho BC: Acquired resistance to cetuximab is mediated by increased PTEN instability and leads cross-resistance to gefitinib in HCC827 NSCLC cells. Cancer Lett 296: 150-159, 2010 